\title{
A Literature Review and Taxonomy of Environmentally Responsible Manufacturing
}

\author{
Sime Curkovic ${ }^{1}$, Robert Sroufe ${ }^{2}$ \\ ${ }^{1}$ Management Department, Center for Integrated Supply Management, Haworth College of Business, Western \\ Michigan University, Kalamazoo, USA \\ ${ }^{2}$ Donahue Graduate School of Business, Duquesne University, Pittsburgh, USA \\ Email: sime.curkovic@wmich.edu,sroufer@duq.edu
}

Received 23 February 2016; accepted 28 March 2016; published 31 March 2016

Copyright (C) 2016 by authors and Scientific Research Publishing Inc.

This work is licensed under the Creative Commons Attribution International License (CC BY). http://creativecommons.org/licenses/by/4.0/

(c) (i) Open Access

\begin{abstract}
Environmentally Responsible Manufacturing (ERM) is a proactive managerial approach encompassing a company's effort to integrate environmental practices into decision-making processes. The ERM body of knowledge is very diverse and has been shaped by research in numerous interdisciplinary areas. In the formative years of the ERM paradigm, this diversity kept researchers from developing a thorough understanding of the status of research within the ERM field, and the more recent proliferation of information has also contributed to a lack of understanding. One method of developing a mastery and familiarity with this body of knowledge is to develop a taxonomy within which the literature can be framed. This is the major objective of the paper. We examine the literature to identify early major dimensions of the taxonomy and discuss how these dimensions have evolved. The major contribution of this approach is that it helps researchers develop a familiarity with the major themes found in a body of knowledge spanning multiple decades. With such a familiarity, scholars can effectively build on and extend the current body of knowledge. For the purposes of this paper, over 10,000 scholarly articles, governmental publications, web-based publications, and books and were examined.
\end{abstract}

\section{Keywords}

Environmentally Responsible Manufacturing, Taxonomy, Sustainability

\section{Introduction}

Increasingly, companies are confronted with the need to reduce their impact on the environment. Environmental responsibility is no longer just a legal or moral obligation—it also makes good business sense. We also find that

How to cite this paper: Curkovic, S. and Sroufe, R. (2016) A Literature Review and Taxonomy of Environmentally Responsible Manufacturing. American Journal of Industrial and Business Management, 6, 323-346.

http://dx.doi.org/10.4236/ajibm.2016.63030 
proactive leadership leading to a reduction of pollution and $\mathrm{CO}_{2}$ emissions means increasing resource efficiency and decreasing waste, i.e., bottom line impacts. Improved health and safety conditions result in a more productive workforce and new human resource opportunities to engage a workforce. Finally, supplying goods and services that minimize the impact on the environment helps to expand markets and improve sales, i.e., top line growth. There has been a lot of research and application by practitioners that provide the foundation for an evolving environmental management paradigm.

Environmental responsibility has been a change agent for U.S. manufacturing firms taking the form of a number of factors, including, but not limited to: government regulations, the advent of ISO 14000 and 26000, Life Cycle Assessment (LCA), the Global Reporting Initiative (GRI), and the potential for organizations to obtain good or avoid bad publicity. This increase in transparency has been supported by other factors within industries (i.e., chemicals and electronics) including WEEE, RoHS, Extended Producer Responsibilities, or Environmental Product Declarations (EPDs), and from external groups, e.g., the Green Cross certification program and Canada's Eco Logo program, or Cradle to Cradle certification, Fair Trade, and Forest Stewardship Council. In sum, we are operating in a world that prizes and encourages Environmentally Responsible Manufacturing (ERM); however, being lean, green, or clean is not an easy task, as there is a myriad of information through which to navigate.

At an Academy of Management Organizations and the Natural Environment (ONE) Division meeting, Andy Hoffman [1] presented trends in Business and the Natural Environment (B \& NE) publications per year, noting the exponential increase in publications taking place in the mid-1990s through to 2010. His sample of almost 900 articles shows research on B \& NE dated back to the early 1970s. It did not fully develop as a substantial body of literature until the early 1990s, and has been growing ever since (see Figure 1), with the mid-1990s setting the direction for the field. Hoffman goes on to find that $73 \%$ of these articles were published in mainstream academic journals (non-specialized), while $27 \%$ were published in journals that focus specifically on environmental issues.

Not only can decision makers and scholars have a hard time keeping track of the amount of information regarding environmentally responsible practices, but standards and requirements are continuously emerging, often vague, and at times, work against each other. In addition, it can be difficult to identify the most appropriate area for attention when implementing or using systems that embody environmental principles, practices, and tools. Finally, there is the issue of how to deal with the trade-offs and tension that being environmentally responsible introduces.

These factors affect not only industry, but also academic research. Increasingly, researchers are being asked to deal with the various issues associated with the environmental attributes of business management and to address and resolve the various paradoxes and obstacles that surround this field of study. However, research within the ERM paradigm is both a very challenging and complex task. In part, this complexity can be traced to the body

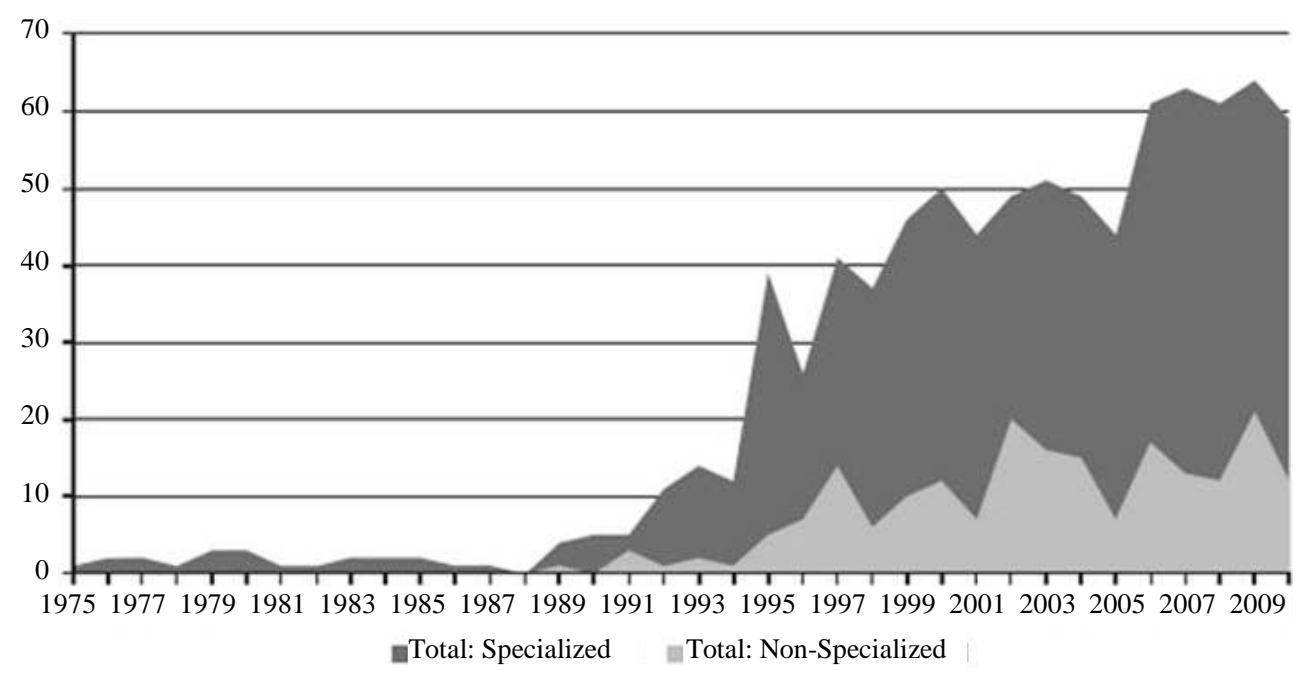

Figure 1. Business and the natural environment articles per year 1975-2010. 
of knowledge on which ERM is based. ERM has many parents and its evolution has been influenced by many different developments while enabling different offspring. As a result, the ERM body of knowledge is very diverse, as it has been shaped by research in such areas as economics, chemistry, ecology, engineering, product design, political science, governmental regulation, accounting, finance, marketing, operations management, and systems thinking (to name just a few of the areas involved).

Considering the diversity of the ERM field, a research agenda would probably be best served by interdisciplinary research teams. However, before we consider the development and operationalization of effective, useful, and interesting research into the field of ERM, it is first necessary that scholars have a thorough understanding of the current status of research within the field and of the major issues and trends. With such a familiarity, the researcher can effectively build on and extend the current body of knowledge.

To do so, the researcher must first come to grips with this diverse and expansive literature that makes up the ERM body of knowledge. One method of developing a mastery and familiarity with any body of knowledge is to develop a taxonomy [2]-[4] within which the current literature can be framed, studied, and opportunities for future research readily identified. This is the major objective of this literature review.

There are two methods of developing such a taxonomy. The first is to use a taxonomy taken from an existing but applicable theoretical base (e.g., resource-based research) and to apply this taxonomy to the literature. The resulting analysis focuses on those areas where the taxonomy indicates that research should be present, but where there is either very little or none present. These areas are then examined to determine potential reasons for this lack of study. The major strength of this approach is that it can direct attention to potential areas of research. The major shortcoming with this approach stems from the potential that the theoretical structure initially selected may not be the most appropriate.

Alternatively, we can examine the current body to identify the major dimensions of an emerging taxonomy. With this approach, the taxonomy is driven by the literature. The major advantages of this approach are that it helps the researcher develop a familiarity with the major themes found in the current body of knowledge (useful when trying to build on this knowledge base) and that it avoids the potential problems associated with selection of appropriate theoretical frameworks. However, such an approach is bound by the existing body of knowledge.

Given the orientation of the literature, this study will use this latter approach to provide new insights not limited by a single theoretical base. Taking this approach in developing a comprehensive taxonomy will capture almost all of the relevant body of knowledge. Furthermore, we will build off of this approach to identify and discuss potentially interesting trajectories of future research in the ERM area.

This study is organized as follows. In the first section, we examine the concept of a taxonomy, the traits associated with a strong taxonomy, and the roles played by such a device in research. The second section provides an overview of what is meant by ERM. The third section focuses on the development of the ERM literature base to be examined. In the fourth section, we describe the research methodology used in developing the proposed taxonomy. The fifth section examines the meta-categories created from the taxonomy. The final section examines several areas which appear to be both interesting and fruitful for future investigation. For the purposes of this paper, over 10,000 articles, governmental publications, Internet publications, books, and published works were examined.

\section{The Concept of a Taxonomy}

A taxonomy has been formally defined as the practice of delimiting and classifying different kinds of entities [2]-[4]; therefore, a taxonomy includes the classification system. All classifications are composed of taxa, which Chrisman [4] define as sets of entities sufficiently similar to each other and sufficiently different from the entities in other such sets that they are separately delimited and named. A classification system, such as the one used for this study, contains at least two categories of taxa.

Chrisman et al. [4] attempt to classify business strategies built on the work of Porter [5] and Abell [6]; however, they also discuss in great detail the attributes of a classification system and the taxa associated with it. The necessary attributes of a classification system and its taxa include:

1) Members of taxa must be more similar to one another than they are to members of other taxa. This is required if valid generalizations are going to be for members of a taxa [7] [8].

2) The taxa of a classification system must be collectively exhaustive [9]. A classification system which leaves anything out is incomplete, and therefore, not as useful to researchers. 
3) It should not be possible to reassign members of a taxa to another if the classification system is properly developed; otherwise, the classification system is invalid [3].

4) Taxa should be given be identified by names which describe the distinguishing characteristics used to delimit them in the first place [10].

The primary role of a strong taxonomy is to provide a foundation for comparing studies [10]. A strong taxonomy is also required to ensure the consistency and comparability among future studies using the same taxonomy [11]. Ultimately, using these approaches described from the literature, a strong taxonomy can be used to identify and discuss potentially interesting lines of future research in the ERM area.

\section{Environmentally Responsible Manufacturing}

In general, environmental responsibility can take either a remedial or proactive approach. With the former, also called "end-of-pipe" solutions, environmental problems are corrected once they have been created. This is relatively ineffective, because it does not attack the causal factors, merely the symptoms. These traditional ways of dealing with environmental issues in a reactive, ad-hoc, end-of-pipe manner have proven to be highly inefficient [12] [13]. To keep the problems from arising, the proactive approach must be used, which focuses attention on the decisions and actions that create the problems in the first place [14] [15]. Using Ackoff's [16] taxonomy of solve, resolve, and dissolve, proactive approaches focus on dissolving problems, that is, trying to ensure they never occur.

Many different labels are used to describe a company's effort to integrate environmental thinking into its decision-making processes. Industrial Ecology [17], Environmentally Conscious Manufacturing [18] [19], and Environmental Operations Management [20] were among the early labels used. An examination of these terms highlights that they differ mostly by their labels and not in core elements. However, Melnyk and Handfield [21] used Environmentally Responsible Manufacturing (ERM) to describe the integration of environmental issues into decision-making processes. They defined ERM as:

a system which integrates product and process design issues with issues of manufacturing production planning and control in such a manner as to identify, quantify, assess, and manage the flow of environmental waste with the goal of reducing and ultimately minimizing its effect on the environment while also trying to maximize resource efficiency.

Compared to the other labels and definitions, ERM as defined above emerges as comprehensive and perhaps salient. Therefore, ERM and its definition described above will be used for the purposes of this literature review. Taking this approach means we have a foundation and focus on the manufacturing context and associated environmental wastes. As the literature will show, this foundation will expand to include sustainability and supply chain management.

\section{ERM Literature Base}

Research on the environment and manufacturing published in refereed journals, conference proceedings, practitioner publications (e.g., Newsweek), books, and monographs were identified for the purposes of this literature review. Increased attention was given to ERM articles in refereed academic journals because of the rigorous review process. However, ERM is still an evolving field within academia. Because ERM issues did not receive much attention prior to the 1970s, the search was restricted to articles published since this time. Only after 1970 did ERM start receiving acceptance as an important topic. The following procedure was used to identify the ERM literature:

1) An exhaustive list of keywords related to the topic area was compiled (e.g., environmental management, environmentally responsible manufacturing, industrial ecology, environmental regulations, etc). The list provided for an adequate search to identify the articles in the area of ERM.

2) The ABI-INFORM ProQuest database was the major database used to identify ERM articles. The database was used for two major purposes: a) ABI ensures a comprehensive coverage of the ERM field in refereed journals; and b) ABI identifies the major keywords associated with each reference which drove the classification scheme.

3) Website pages were also used to locate working papers and conference proceedings to identify unpublished ERM articles. 
4) Each article identified in steps 2 and 3 were reviewed. Any article whose focus was on environmental issues was classified as an ERM article and was entered into an ERM database. Only those articles written outside the context of environmental issues were eliminated from further consideration and were not classified as ERM articles.

5) The bibliographies of the articles passing step 4 were also used to identify any other relevant articles which may have been missed in the computerized search. Again, for any newly independent articles, step 4 was repeated. Relevant ERM articles in journals found during the cross-reference that were not included during the search were also added to the database of ERM articles.

This procedure ensured a comprehensive examination of the body of literature as it pertained to the ERM field. With very few limitations, over 10,000 references were identified for examination. These references were collected and pooled into an ERM database. The database permitted all articles from ABI to be downloaded directly into the ERM database in abstract form.

\section{Methodology}

Each reference in the ERM database lists a number of keywords associated with it. A total of approximately 2000 different keywords were identified among the over 10,000 references in the database. These keywords were used as the foundation for the classification scheme. Dealing with around 2000 keywords was more manageable than working with 10,000 references in abstract form. These 2000 keywords appeared in the database over 100,000 times. Meaning, most keywords appeared in more than one reference. Similar and related keywords were categorized into mutually exclusive meta-categories; meaning, none of the meta-categories shared keywords. For example, keywords such as employee involvement, employee development, and human resource management are all related, and were subsequently placed into a meta-category called Human Resource Development. The keywords associated with each reference formed the classification scheme from which 9 mutually exclusive meta-categories were identified.

However, only around half of the keywords were placed into a meta-category. These keywords appeared or accounted for around half the hits in the database. The remaining keywords were labeled as residuals because they were too vague or broad to be placed into one of the meta-categories. For example, externality was a keyword in the database; however, it was too vague to be accurately placed into a meta-category. Another keyword such as stakeholder was too broad and could have been placed into more than one category.

A random sampling exercise of the residual keywords list was used to add credibility to the classification scheme. Almost all of the residuals actually belonged in one of the 9 meta-categories. These keywords should not have been labeled as residuals. Only a very small percentage of the keywords in this exercise actually belonged in the residuals category. These keywords could not be placed into one of the meta-categories because the references associated with the keyword were not related.

\section{Meta-Categories}

This section will identify the major developments in each meta-category. The meta-categories which emerge from the literature include: 1) Environmental Regulations; 2) Information Analysis, Planning, and Performance; 3) Process Management; 4) Pollution Prevention; 5) Anecdotal Case Studies; 6) International Issues; 7) Quality-Based Approaches; 8) Human Resource Development; and 9) Management Leadership. The categories are presented in order from the largest number of hits in the ERM database to the smallest.

\subsection{Environmental Regulations}

Examples of the keywords in this meta-category include Clean Air Act, Environmental Regulation, Clean Water Act, and Federal Regulation, and are the early drivers of ERM. This meta-category accounted for the largest number of hits in the ERM database within the early decades in this field. This category has been evolving to include WEEE, RoHS, Extended Producer Responsibility, GHG and $\mathrm{CO}_{2}$ emissions, and regulations involving Cap and Trade such as the Kyoto Protocol.

Most of the literature discusses in great lengths the conditions associated with federal regulations such as: 1) Resource Conservation and Recovery Act (RCRA); 2) Comprehensive Environmental Response, Compensation, and Liability Act (CERCLA); 3) Superfund Amendments and Reauthorization Act Title III (SARA Title III); 4) 
Clean Air Act (CAA); 5) Clean Water Act (CWA); and 6) Occupational Safety and Health Act (OSHA).

Three approaches for firms to take when dealing with environmental regulations emerge from the literature [21]-[24]. 1) They can ignore them completely (i.e., noncompliance), which during the 1970s was an option, but no longer is. 2) They can take on a compliance approach, which the literature identifies as being the most popular and dangerous, given the retroactive nature of environmental laws. 3) Finally, firms can take a leadership role in which policies and procedures of these companies become the standard for others and where case-study research and anecdotal evidence help to build grounded theory. In general we find the advantages associated with leadership tend to be greater than those associated with compliance [21]; however, the stage of development of environmental regulation for an industry is noted to prompt some firms to try to lead the industry, while many others firms wait [25] [26].

Voluntary programs created in the 1990s enabled the EPA to be a resource for making companies more efficient [27]. The agency’s early voluntary programs include: 1) 33/50; 2) Climate Wise; 3) Green Lights; 4) WasteWi\$e; 5) Energy Star Computers; 6) Energy Star Buildings; and 7) Design for the Environment. Many concerns with voluntary programs boil down to issues of coordination [22]. Trends show an increase in voluntary program and more transparency with the Global Reporting Initiative (GRI); Carbon Disclosure Project (CDP) having almost $100 \%$ of the Fortune 500 firms and the world's largest companies now reporting [28] [29], along with widespread use of the Greenhouse Gas (GHG) Protocol.

Some view, environmental regulations as either benign as to their impacts on international competitiveness or actually as a net positive force driving private firms and the economy as a whole to become more competitive in international markets. An early debate can be found in the literature revolving around these two views. A 1994 Harvard Business Review article uses twelve experts to assess both viewpoints. Porter and van der Linde [30] claim that the environmental regulation-competitiveness debate has been framed incorrectly. The authors argue that properly designed environmental standards can trigger innovation that may partially or more than fully offset the costs of complying with them and this claim is supported by later research, i.e., Greenstone [31]. Xing and Kolstad [32] show that lax environmental regulations will attract foreign direct investment in heavy polluting industries, with other work showing first-mover advantages to these locations [33] [34].

This meta-category was the foundation for much of the early compliance-based thinking, and a view that environmental regulations force cost/performance tradeoffs. Research has shown that tradeoffs can be considered a binary description and blinder to a dynamic and complex reality. This category is ripe for further scholarly research as there has been and will be no slowdown in international, federal, and state level regulations, calls for transparency, or voluntary programs.

\subsection{Information Analysis, Planning, and Performance}

Examples of the keywords in this meta-category include: Information Management, Information Technology, Financial Planning, Business Performance, Environmental Accounting, Environmental Management Systems (EMS), and Remanufacturing. This meta-category accounted for the second largest number of hits in the ERM database.

Fundamental to ERM is collecting relevant information from all phases of an organization's operations and using it to monitor and improve environmental performance. ERM requires extensive information collection and analysis and the latest technology for managing information resources [35]. Information technology can help reinforce the implementation of ERM practices [36]-[39]. By applying the tools of information planning to ERM, a company's information infrastructure can be aligned with strategic goals and business processes [40]. The challenges facing ERM companies is that environmental data usually resides in parallel information systems apart from other corporate data [41] and needs to be extended to include closed-loop systems and remanufacturing [42].

The literature identifies that a company's ability to accurately reflect the costs and benefits associated with current or proposed products and processes is the most critical information required in order for an ERM initiative to be given serious consideration [18] [43]. In other words, ERM initiatives must be justified from an economic standpoint. A major barrier to obtaining environmental cost information is uncertainty. Given the profit objectives of businesses, a process is still required for evaluating ERM initiatives by appropriately including environmental costs and savings for investment options [44] [43].

Porter and van der Linde [45] claim that companies must improve their ability to collect environmental cost 
and savings information; otherwise, companies will be ill-prepared to carry out a strategy of environmental innovation that produces sizable compensating offsets. Through a series of case studies, Royston [46] demonstrates that the economic way to abate pollution is to predict future waste treatment costs in the light of present expenses, with Rusinko [47] supporting these claims and Zhu and Sarkis [48] extending this further with an international context of manufacturing in China. Even policy makers base environmental planning on the careful balancing of benefits and costs [21].

The importance of environmental cost information systems has been disseminated widely within the environmental literature as consultants, academics, and practitioners believe information systems improve environmental performance [49]. However, according to authors [50]-[53], most accounting systems and capital budgeting processes do not provide enough information. The general consensus is that accounting and capital budgeting methods are biased toward end-of-pipe technologies [44]. More research is required which promotes the design and development of better accounting and capital budgeting practices with firms' managerial accounting systems. Research in this area has provided new information from services such as KLD, now called MSCI Global Socrates, and Trucost who analyze and disseminate Environmental, Social, Governance, and GHG information on publicly traded firms.

Organizations that are able to plan and organize their resources are better able to meet or exceed their environmental performance expectations [37] [53]-[57], which also extend into supply chains [58]. The input to the strategic planning process is the collection and analysis of all pertinent information. The strategic planning process ensures that: 1) ERM issues will become an integral part of planning; and 2) a process will be in place to communicate with customers and stakeholders and include their input in planning [59] Buysee and Verbeke, 2003). One important dimension on which companies must strategically compete is the response to customer and stakeholder demands about the environmental impacts of products during and after use [54]. All systems involved in the production, delivery, circulation, use, and disposal of products must be analyzed to confirm that they have no adverse impact on the environment [60].

To develop a strategic orientation, Hunt and Auster [61] early on claim that ERM goals must also become part of the annual business plan with an annual performance review to track progress that is supported by Govindarajulu, and Daily [62]. Further calls for integrated systems use Environmental Management Systems (EMS) as a resource to enable the measurement and management of ERM activities inside and outside the organization [63] [64].

The roles of functional managers in strategic planning for ERM is not reflected in most early articles and is still called for after decades of research. The dynamic context of ERM information analysis and planning calls for the use of new mutlicriterion tools to integrate available data and cross-functional thinking [65]. More focus is needed on the integrated nature of planning since ERM is ultimately a cross-functional undertaking [66] [67] [69]. Finally, there is a clear trend toward further advancement of information systems and accounting approaches to analyze the true costs and full value of all decisions.

\subsection{Process Management}

Examples of the keywords in this meta-category include: Design for the Environment, Production Processes, Green Marketing, Supply Chain Management, and Green Suppliers. ERM works on the belief that enhancements can be made by improving the processes directly related to creating products. In addition to manufacturing, supporting functions such as marketing and accounting play key roles in making ERM programs more effective. Therefore, ERM must encompass all phases of production and all supporting functional areas.

ERM is ultimately a cross-functional undertaking affecting all functional areas of a business enterprise [66] [67] [69]. ERM brings together people from different functional areas. A separate and distinct department for ERM can cause other parts of the organization to ignore ERM issues since "someone else" is responsible for them [23]. The literature recognizes these linkages by identifying major focus areas for managing ERM effectively: 1) product design and production processes; 2) support business processes; and 3) supplier's environmental performance as internal operations are linked to supply chains.

\subsubsection{Product Design and Production Processes}

In terms of an organization's ERM activities during the various production phases, research has focused on the preproduction (product design and development) and production stages. A few case studies look at methods for 
achieving ERM goals within manufacturing by introducing new process techniques [70] [71]. While much progress has been made in developing these models, they have not been integrated with one another to create a system that allows for assessment of overall performance and the trade-offs therein. More recent ERM integration involves three-dimensional concurrent engineering [72]. However, in most process management articles, it is mentioned that the greatest opportunities for waste minimization are during the design process [74]-[76].

As it is generally used, the term Design for the Environment (DFE) means making environmental considerations an integral part in the design of a product, process, and/or technology [77]. The concept of DFE originated from industry's effort to target specific environmental objectives for design engineers to incorporate when creating a new product. The goals of ERM can only be achieved when environmental issues are identified and resolved during the early stages of product and process design, when changes can be made to reduce or eliminate environmental waste [24] [77]-[80]. The literature does not address why DFE and its usage has not become widespread. Some examples and situations (i.e., case studies) are provided where it has proven to be successful (e.g., AT \& T and DuPont), but these are limited to a very few companies [81] [82]. The early literature ignores the obvious interrelated relationship between process and design issues.

It becomes very clear from the literature that there is a lack of appropriate measures and tools for capturing environmental impacts of product designs and production processes. However, the literature suggests that the same tools used for the foundation of TQM can be used to indicate potential avenues of waste reduction [43] [53] [59] [83] [84]. The Global Environmental Management Initiative [105] recommends that quality-based tools such as Pareto analysis, root-cause analysis, and continuous improvement be used to identify and prioritize ERM issues, identify alternative approaches, construct practical plans, and allocate scarce resources. For ERM, statistical tools are particularly appropriate for eliminating errors in sampling and monitoring procedures [87]. Data-driven tools which are relevant to TQM principles can be integrated into ERM [88]. We conclude that the potential for these techniques and tools in ERM are not being fully exploited at a basic level within firms.

Life-cycle analysis (LCA) is perhaps the most effective ERM tool cited in the literature [89]. Life-cycle analysis is a system-oriented approach that estimates the environmental inventories (i.e., waste generation, emissions, and discharges) and energy and resource usage associated with a product, process, or operation throughout all stages of the life cycle. It is recognized as a more effective tool when used properly than the other tools previously mentioned [90] and utilized for internal assessment and supplier assessment [91] [100]. The literature highlights a lack of standards and tested methodology. There is also no data within most companies to support the use of life-cycle analysis (i.e., sources and amounts of pollutants). Future research should focus on developing accepted standards and methodologies for using life-cycle analysis for ERM. Gloria, Saad, Breville, and O’Connel [92] contend that life-cycle analysis has many shortcomings that need to be addressed. According to these researchers, the concerns of poor data quality, data availability, high implementation costs, subjectivity, and a lack of standardization have prohibited early acceptance of life-cycle analysis.

\subsubsection{Support Business Processes}

The role of support functions in ERM implementation and environmental quality assurance have been largely overlooked with the exception of marketing. Morgan and Munilla [93] suggest that the eco-marketing orientation is an emerging strategic response by some organizations to the turbulent social and natural environments of the 1990s. Most studies agree that environmental marketing will be an integral part of corporate life in the 1990s and beyond, affecting everything from product and packaging through positioning and promotion [68] [94] [95] Unfortunately, environmental claims have been described as confusing, misleading, or outright illegal [96]. To avoid these greenwashing issues, the ISO 14000 series of standards provides guidelines for product claims. A few early studies developed frameworks and identified the sequence of actions necessary for the development of practical green environmental marketing strategies [94] [97]; however, there is still a gap in the literature that examines marketing's role and involvement in environmental quality assurance. More research outlining the role of marketing and the other support functions in implementing ERM programs is necessary.

\subsubsection{Supplier Environmental Performance}

The prospect of optimizing the environmental performance of the supply chain and addressing the application of ERM activities to the procurement process is not a new topic. A survey of buying responsibilities among top 100 purchasing organizations in the U.S. found $65 \%$ with some form of environmental, hazardous waste treatment, 
or source reduction duties in the early 1990s [98]. Researchers have used three major approaches to better understanding the implementation of environmentally responsible supply chain management: 1) drawing parallels with the implementation of quality, and, to a lesser degree, cost reduction and timeliness improvement programs [99]; 2) conducting early empirical work with computer design firms and their suppliers to learn about progress already made and to draw additional parallels with the implementation of quality programs [71] and 3) searching for theoretical management models that will lead to fundamental understandings of the interactions among firms on environmental issues [75] [76] [100].

Sheng, Beckman, Rosen, Worchach, and Berkowitz [71] develop a hierarchical metrics for environmental performance at the process, product, and organizational levels and provide a framework for environmentally friendly supply chain management. One of the theoretical frameworks they are exploring as a means of understanding environmental supply chain management is transaction cost economies (TCE). TCE provides an analytical and predictive methodology for understanding and classifying interactions among firms.

ERM recognizes the implications of the supply chain for its environmental quality assurance activities. The overall success of ERM is greatly influenced by the actions of its suppliers [98]-[100]. While not commonplace decades ago [101] [102], many companies are now including ERM issues in discussions with suppliers due to efforts by firms like Walmart, P \& G, and Unilever. Yet for many firms, the supply chain represents a major challenge, since they may not have the ability to directly influence or monitor the environmentally related actions of suppliers. The expansion of ERM across supply chains provides dynamic opportunity for research and analysis of how environmental efficiency has expanded to provide decision makers with more internal process/ product data and supplier performance information than has ever been available before. Included within the scholarly work on this topic, there are now a myriad of books on clean, green, responsible, and sustainable supply chain management practices.

\subsection{Pollution Prevention}

Examples of the keywords in this meta-category include: Pollution Prevention, Waste Minimization, Avoidance, Source Reduction, and Proactive Strategy. Similar to the proactive approaches used by the Japanese in quality management, a prevention mindset is perhaps the most important element of an ERM program.

Early research and conceptual thinking on ERM focused only on the concept of pollution control [103]. However, it has been commonly accepted that there are great benefits to eliminating pollution at its source rather than installing end-of-pipe controls [12] [104]. Traditional ways of dealing with environmental issues in a reactive, ad-hoc, end-of-pipe manner, have proven to be highly inefficient [105]. Klassen and McLaughlin [54] bring to attention that the gradual evolution of the "quality of life" and the environment has already been anticipated by Japanese authors. Mizuno [60] favors active quality management that anticipates and works within the constraints of the system without missing any customer requirements.

The environmental management hierarchy according to the EPA includes: 1) prevention; 2) recycling; 3) treatment; and 4) disposal or release. The EPA "Statement of Definition" is a formal embodiment of what has been the Agency's working definition of pollution prevention [27]. Pollution prevention means source reduction, i.e., any practice which: reduces the amount of any hazardous waste substance, pollutant, or contaminant entering any waste stream or otherwise released into the environment prior to recycling, treatment, or disposal; and reduces the hazards to public health and the environment associated with the release of such substances, pollutants, or contaminants. The term includes: equipment or technology modifications, process or procedure modifications, reformulation or redesign of products, substitution of raw materials, and improvements in housekeeping, maintenance, training, or inventory control. Under the Pollution Prevention Act, recycling, energy recovery, treatment, and disposal are not included within the definition of pollution prevention, and there are gaps in the literature as energy efficiency gets more attention from production management [106].

Articles pertaining to pollution prevention introduced different forms of prevention (i.e., recycling, recovery, reclamation, composting, etc.). The environmental impacts of minimization and prevention were discussed more than the economic impacts. A few early research studies have focused on the cost-effective nature of pollution prevention. Royston [46], through numerous case examples, was one of the first to offer considerable evidence that proactive companies can turn pollution prevention into profit and make their growth and survival congruent with environmental protection. Later, Smart [50] used the case histories of 24 companies to examine what does and does not work in terms of cost-effective pollution prevention, and other research started to surface in the li- 
terature which went beyond environmental benefits. Other researchers throughout the 80s and 90s have also demonstrated that the benefits of pollution prevention extend beyond waste reduction [18] [21] [107]-[110]. However, the early need for pollution prevention investments is not universal among managers [21] [111]. Surveys of CEOs reflect a different emphasis. Via surveys, environmental issues were consistently ranked fifth or lower in importance to business, while quality ranked as number one [44] [112] [113].

The question has been asked, does the market value pollution prevention and environmental performance? As we move from anecdotal evidence to empirical analysis, there is mounting evidence to show the answer to this question is yes [57]. The literature remains focused on end results and accomplishments of leading companies. However, it ignores implementation/process issues, methods for achievement, and hurdles for success at its own peril, as these research insights are generalizable to the many companies where there is a negative perception of pollution prevention and a missed opportunity to change dated practices. For some organizations and scholars, crossing the chasm to ERM takes evidence of proven benefits from other firms and grounded theory development. This field-based research is explored further in the next meta-category.

\subsection{Anecdotal Case Studies}

Examples of the keywords in this meta-category include: Case Studies, Field Study, Conceptual Analyses, Best Practice, and Environmental Experts. Most of the company references in this meta-category can easily be found in the popular press literature. Articles in this category focused on corporate success stories and firms that promoted ERM policies and programs. They point out the need for companies to adopt a proactive posture if they are to maintain a competitive advantage and respond to a powerful "green" consumer movement [114] [115]. Consistent themes in these proactive companies were top management commitment to ERM and the implementation of policies and programs which are both environmentally responsible and cost-effective.

A number of early books probe industry's role in ERM by presenting conceptual analyses and anecdotal case examples of firms operating with superior environmental performance. Each book provides a slightly different perspective and offers prescriptions for how ERM should evolve. These books are similar in their focus on creating a sustainable future. An early catalyst for changing thinking would have to be Rachel Carson's Silent Spring (1962) which also led to the formation of the EPA. Former Vice-President Al Gore in Earth in the Balance [116] sings the praises of ERM by arguing that it is often the best way to increase a company's efficiency, and therefore, profitability.

Cairncross's Costing the Earth [117] stresses the role of government agencies to create alliances with industry, how to foster sustainable development, and advocates the government's role in designing more innovative environmental policies which support both economic growth and a cleaner environment. Schmidheiny [118] in Changing Course, explores the economic aspects of ERM in detail, advocating for technological changes while recognizing that changes in the goals, assumptions, and tools used to reach them are also required. Stead and Stead's Managing for a Small Planet [119] also explore the economic aspects of ERM calling for a new paradigm which includes the environment as a critical component, so that corporate managers can begin to integrate the environment into their strategic decision-making.

These books provide early prescriptions for how ERM should evolve. While these books provide an overview of how corporations need to change, Makower's [22] The E-Factor explores internal corporate operations in more depth and how environmental issues affect all areas of a company's activity. Next, Makower's [23] Beyond the Bottom Line argued that environmental issues affect all of the functional areas of a business enterprise, including the management of human resources, operations, research and development, marketing, and strategic positioning.

Emerging themes from these books include treating the environment as an economic opportunity; incorporating environmental issues into decision-making processes throughout a company's operations in both environmentally friendly and profitable ways; and links between the environment and quality. Considering that waste and pollution are defects (in that they result from inefficiencies in the system), Makower follows that an ultimate goal of environmental quality is to achieve zero waste and pollution as a predecessor to John Elkington's [120] book on Zeronauts highlighting innovative individuals and companies determined to drive problems such as carbon, waste, toxics, and even poverty to zero. Applying the Principle of Green Engineering to Cradle to Cradle Design [121] is a celebrated industrial manifesto whose authors (a chemist and architect) also take inspiration from the robustness of natural systems to recommend technological change. Savits and Weber [122], want 
companies to focus on the "triple bottom line": solid profit, environmental quality, and improved human welfare.

A final look at impactful ERM-related books with best-in-practice examples includes the New Sustainability Advantage, which succinctly summarizes bottom-line benefits of sustainable practices in relevant business terms. In a Forrester survey of over 2,000 executives regarding top 10 business priorities in 2011, 64\% of executives selected revenue and customers, $44 \%$ selected cost reduction, while only $10 \%$ selected corporate social responsibility (CSR). For CSR professionals, messaging the revenue increase and cost reduction benefits of CSR efforts continues to be a key in driving implementation.

To further the ERM paradigm, the popular business press literature and much of the existing research literature continue to present conceptual analyses and anecdotal case studies of ERM firms. However, as noted by Cairncross [117] and Klassen [26] two decades ago, anecdotal examples of ERM firms are often difficult to generalize between firms, and managers, of course, are more interested in broad, general managerial approaches.

\subsection{International Issues}

Examples of the keywords in this meta-category include: ISO standards, European Community, International Markets, and Global Environmental Management. The forces of ERM drivers vary by region, and literature within this meta-category looks at these forces within and between regions [123] [127]. The common theme within this category is that U.S. multinational firms need to broaden their environmental horizons. The environmental requirements of some overseas markets such as Western Europe are more stringent than in the U.S.; therefore, U.S. multinational corporations tend to get better returns on environmental investments than U.S. companies without any overseas experience [124].

The literature addresses how industry associations, standards bodies, regulatory agencies, and companies have been working together to develop global guidance for environmental management. In Europe, there is the imposition of common and stringent environmental standards, such ISO 14000 (environmental management systems) decades ago, and 26000 (social responsibility) more recently. Even the North American Free Trade Agreement (NAFTA) attempts to create a level playing field among the U.S, Mexico, and Canada by standardizing certain environmental regulations. Comparable developments are underway in many Pacific Rim nations.

The literature claims that it may be easier for companies to try new environmental technologies in other parts of the world than in the U.S [55] [125] [126]. The daunting task for U.S. multinational firms will be to implement uniform environmental management practices as they are driven by the convergence of national compliance requirements and location [125] [127]. Purchasing is and will continue to be pivotal to integrate ERM concerns internationally [128]. However, the literature fails in describing how this can best be accomplished, with [126] suggesting that ISO 14000 standards may serve this purpose best, while Wagner and Schaltegger [129] have shown how corporate environmental strategies and environmental Performance have an impact on competitiveness and Performance.

Research needs to address whether ISO 14000 will be widely used by businesses as a consensus model, and whether it should be. Instead, the literature is replete with conflicting predictions and viewpoints offered by experts [85] [100]. These naysayers claim that the documentation associated with ISO 14000 will make a tempting target for regulators and having a system in place for compliance does not necessarily lead to compliance. However, champions of ISO 14000 suggest that it will unify countries in their approach to environmental management and will be looked upon more favorably than traditional, governmental measures [100]. ISO 26000, adopted in 2010 is the international standard developed to help organizations effectively assess and address social responsibilities issues that are relevant to their mission and vision; operations and processes; customers, employees, communities, and other stakeholders; and environmental impact, and, as it is newer, has received less attention by scholars than its better established 14000 sibling [64] [80] [130]-[133].

International issues, much like the other meta-categories add to the complex reality facing practitioners. There is a need for scholars to obtain access to both secondary and primary data sources to uncover operational factors linked to the standards and regulations that dictate ERM practices. In this increasingly global world, this category of the ERM field will only be expanding.

\subsection{Quality Based Approaches}

Examples of the keywords in this meta-category include: TQM, Benchmarking, Quality, Lean, and Continuous 
Improvement. Researchers suggest that companies with Total Quality Management (TQM) programs in place usually undertake more effective environmental investments than companies with less commitment to TQM [22] [44] [54] [88] [134]-[139]. They all claim that both TQM and ERM: 1) aim to improve a company’s final output; 2) require some new definitions of leadership; 3) emphasize long-range planning over short-term considerations; 4) involve changing relationships between companies and their employees, suppliers, and customers; 5) strive for a cultural change; 6) stress improved information, communication, training, and accountability; and 7) demand continual self-assessment, integration and improvement.

According to the literature, the most straight-forward way to develop the link between business' economic self-interests and protection of the environment is by linking TQM and ERM [22] [137] [140]-[142]. The demonstrated similarity between TQM, Occupational Health and Safety, and ERM [139] suggests that in TQM, there is an explainable, understandable, and documented path to ERM. For example, Klassen and McLaughlin [54] suggest the need for an empirical investigation which examines whether firms with advanced TQM programs in place have more advanced ERM programs than firms just initiating TQM. A case study analysis by Post and Altman [143] identified that a firm's ability to reframe learnings from TQM programs is crucial to being environmentally responsible, while Pun [144] supports this going further to find policy and performance evaluations are determinants to ERM success. AT \& T, Eastman Kodak, and Xerox, former recipients of the MBNQA, were among the first to expand their TQM initiatives into ERM initiatives to improve profitability [145] [146]. These examples suggest that TQM precedes ERM; however, there appears to be integration opportunities and the precedence argument remains elusive while examples of empirical work in the field continue to grow [147].

\subsection{Human Resource Development}

Examples of the keywords in this meta-category include: Employee Involvement, Human Resource Management, Employee Development, Empowerment, and Rewards. The articles written during the 1970s and 1980s mostly address regulatory-mandated worker safety issues which were often industry specific. During the 1990s there was still an abundance of articles describing EPA and OSHA involvement in worker safety issues; however, the literature suggests that the best results from ERM can only be obtained when there is a high level of commitment and involvement from people [59].

A team orientation that uses the knowledge of employees to develop solutions for waste problems is a relevant TQM principle that has been integrated into ERM. Using such a team orientation for ERM has been advocated for some time by a number of special interest groups, such as the Global Environmental Management Initiative [148] and the Council on Environmental Quality [86].

Research suggests that using employee involvement teams for ERM is the most effective approach for most organizations [88] [149]-[152]. Training and reward systems can shape employees' positive attitudes about their company’s commitment to ERM [20] [152]-[154].

The key elements of how a company develops and realizes the full potential of the work force to pursue the company's environmental performance objectives are opportunities for further work in the field. Govindarajulu, and Daily [62] highlight the importance of management commitment, empowerment, rewards, and feedback to performance while Daily and Huang [155] include the need for environmental training. The literature also has not examined the impact of ERM programs on the roles and responsibilities of all levels of management.

\subsection{Management Leadership}

Examples of the keywords in this meta-category include: Senior Management, Executive Commitment, Innovation, Strategy, and Leadership. Articles during the 1970s and 1980s addressed top management's role in noncompliances among companies known as environmental laggards. If there is one lesson that can be learned from the study of systems such as JIT and TQM, it is that top management support is critical [156]. However, a major obstacle in dealing with environmental issues is a strong bias in favor of ignorance at the highest levels of the firm. Regulatory agencies responded by making managers criminally liable and responsible for their company’s environmental practices. The literature during this time period is replete with cases of top management officials which have been criminally charged on behalf of the companies they represent.

During the 1990s, anecdotal case examples indicated that the critical guide and motivator for the development 
and implementation of ERM must come from senior management [17] [44] [61] [109] [157]. Often, a cultural change is necessary within management to purge the concept that waste and pollution are inevitable [158]. Adopting ERM requires a fundamental change in the way an organization does business. Therefore, a buy-in is required from senior management to create a cultural change within the organization [59]. ERM requires that management is directly involved in ERM processes as a leader and role model [22]. Key areas to focus on included manufacturing strategy, technology, quality, intra and inter-firm diffusion of best practices [159]; innovation [160]; and complementary assets [161].

As we moved into the 2000s, manufacturing strategy and sustainability merge but are still seen as novel [104] and in need of strategic assessment and decision tools [162]. According to researchers, the organizational issues which top management need to address include but are not limited to: 1) the amount of management support required to assess the full range of alternatives; 2) the type of administrative systems required which will encourage innovation; 3) the types of rewards/positive feedback required for innovations; 4) how to get communication among operating, engineering, environmental, and accounting personnel; 5) strategy development; and 6) innovation. However, the key elements of how senior executives' personal leadership and involvement in creating and sustaining ERM goals are largely unexamined in the literature.

\subsection{Summary}

Contributing to the significant positive trend in publications found by Hoffman [1], there have been a number of calls for papers with special issues on green, environmental, and sustainability issues within manufacturing based scholarly publications.

Production and Operations Management (2001, 2003, 2005)

Journal of Operations Management (2007)

International Journal of Production Economics (2007, 2012)

Supply Chain Management: an International Journal (2008)

Journal of Cleaner Production (2008)

Journal of Supply Chain Management (2009)

International Journal of Physical Distribution \& Logistics Management (2010)

International Journal of Operations \& Production Management (2012)

Decision Sciences Journal (2012)

Journal of Purchasing \& Supply Management (2012)

This increased attention to ERM issues further substantiates this research paradigm and the continued trajectory of work well into the future. The taxonomy developed in this literature review will serve other researchers and practitioners well as a foundation for what has already been accomplished.

A review of the major developments within nine meta-categories reinforces the dynamic nature of the ERM paradigm. This systematic review of ERM literature has identified key themes and issues, and outlined the role that this paradigm could play in the achievement of more responsible business manufacturing and management. The review of the literature has provided a number of useful insights into the current status of scholarship, and how ERM is defined and operationalized. The early and continued emphasis on anecdotal data/methods and theory development across the literature illustrates the evolving nature of this field. Despite decades of advancement, the continued need for further development in a focused and empirical way will include item development, hypothesis testing, and enabling the validity and reliability necessary to ensure the ERM field's continued place as an established research discipline. Greater and more practical insights into manufacturing, sustainability, and supply chains will be gained by using the findings of this review to inform and direct research from the current disparate approaches towards a more integrated, cross-functional field of study.

\section{Directions for Future Research}

A discussion of developments in each of the meta-categories helps identify previous efforts in the ERM field. Another major objective of this literature review is to use these previous efforts to determine the required direction for future research. In order to further integrate ERM into the mainstream [159] and to advance an integrated approach to operations, we propose several directions for further research. We start by expanding on the definition of ERM used to ground this study by proposing a more dynamic and contemporary approach to its definition and future use. Building on prior work in the ERM field and this literature review, we propose ERM be 
defined as:

"a system grounded in quality management which integrates product and process design issues with manufacturing production planning and control, process management, and data analytics, to identify, quantify, assess, and manage the flow of all forms of waste with the goal of reducing and ultimately minimizing negative manufacturing effects on the environment while also maximizing resource efficiency, human resource development, and proactive management opportunities”.

The next section examines the issues which are opportunities for further investigation and emerging trends that require future research in order to develop ERM into a more formal research discipline.

\subsection{Implementation Issues}

Managers may embrace the concept of ERM without understanding its short-and long-term impact or the extent of commitment required at all levels, as the key elements which lead to successful ERM programs in organizations are not well understood [26] [44]. Without clear guideposts, even the most environmentally sensitive CEO will be lost. Managers need a methodology for discovering solutions that yield the greatest benefits [52]. Early books on this topic suggest that competitive advantage can be found in effective ERM programs, yet these books offer a mostly one-dimensional prescription [116]-[119]. Early books on ERM conclude that corporations need to develop ERM programs to remain competitive; however, they need specific guidance on implementation issues which are generalizable between firms [163]. Later books by Makower [22] [23] and others, are broader in their scope and the integration of sustainability calling for closed-loop systems [21], sweeping changes of whole industries [43] [55] [164], a triple bottom line approach to performance measurement [122], and the business case for selling ERM ideas and practices to now even including books on developing sustainable supply chains [80] [130].

The review of the literature points to the limitations of knowledge in the area of ERM implementation. While many firms have adopted ERM programs, their implementation has not been equally successful [51] and rarely implemented across whole industries. The reasons for implementation failure are not well understood and an opportunity for future research. The ERM literature does examine linkages among the various constructs and their impact on performance, and several elements of ERM programs have emerged from reported case studies, conceptual papers, and empirical research. For example, management leadership, written policy, long-term planning, and strong auditing programs are among the commonly implemented elements of ERM programs. However, due to a paucity of insights into the interactions among these various elements, organizations not fully committed to ERM employ them in isolation, or in piecemeal fashion. Hence it is first important to develop ERM theory, investigate linkages among the elements of an ERM program, and identify the ones that are critical for successful ERM implementation. A majority of the writings within the ERM literature have provided managers with normative prescriptions and managerial guidelines, but have fallen short of addressing what could be the most important piece of the equation: how to start or implement a successful ERM program?

\subsection{Performance Relationships}

The relationship between ERM and business performance itself has been the subject of great debate in the early literature and is typically used in the opening statements of journal articles calling for more research to confirm or deny these claims. ERM for a long time has been viewed as a major cost and was normally thought of as involving a tradeoff between social benefits and private costs [21] [24]. However, Harvard Business School Professor Michael Porter [165] introduced a very different perspective. Porter argued that the perceived conflict between environmental protection and economic competitiveness was a false dichotomy. He noted that corporations could contribute to waste reduction and ultimately profit improvements by focusing on ERM. Since then, this observation has contributed to an exponential growth of work in this field from both managers and researchers.

For decades managers held the view that environmental improvement and company competitiveness represent a zero sum game. In other words, ERM was viewed merely as an added cost or as a token effort to do what's right as a corporate citizen [12]. To further fuel the debate, results of empirical research have been mixed, with conflicting conclusions [26] [166]-[168]. This paradox continues to plague the acceptance of ERM and any subsequent research associated with it. For example, Walley and Whitehead [51] and others [124] [169]-[174] have 
challenged Porter's premise that ERM supports improved performance. Yet we find ample evidence of positive relationships to improved firm performance [37] [49] [54]-[58] [64] [80] [129]-[133] [142], to name a few of the more cited works in the literature.

To those firms who are able to resolve the paradoxes of ERM, there await numerous rewards and benefits previously hidden, but now evident [21] [24]. The literature presents numerous examples where environmental investments produce net benefits for private companies with early work by Royston [46] [175]-[179]. While the use of anecdotal cases to develop normative prescriptions and managerial guidelines has served an important function in the early development of the ERM field, the research challenge ahead is to develop the link between business' economic self-interests and protection of the environment [30] [43].

ERM is at the heart of the measurement and reporting movement. Increased transparency along with the internal and external reporting of performance, position ERM at the center of these critical activities. This reporting extends out into whole supply chains, includes the CDP and GRI as de facto international standards, and places ERM practitioners and scholars in a unique space with access to emerging performance data and evolving environmental management systems.

\subsection{Other Related Factors}

Some of the factors which are identified as influencing the success of ERM programs which were not highlighted during discussions of the developments within the meta-categories include:

1) The type of industry can greatly influence an organization's ability to exploit its environmental investment opportunities. Many companies in specific industries have exhausted many of the relatively easy energy, waste, and resource-efficiency options. There are also differences in the relative success of environmental investments within one industry and between industries. Industry variables such as maturity, can either simplify or complicate the success of environmental investments [54].

2) Many companies, especially small and midsize ones, still have more opportunities for successful environmental investments than the larger ones [180] [181].

3) The overseas experience of companies can influence the return on environmental investments. The environmental requirements of some overseas markets such as Western Europe are more stringent than in the U.S. Therefore, U.S. multinational corporations tend to get better returns on environmental investments [124].

4) The external orientation of a company can impact its competitiveness. Firms are more likely to be competitive by anticipating customer requirements, both internal and external [60]. To promote the external orientation, some undetermined level of communication must exist between customers, the public, regulatory agencies, and the firm [61].

5) When looking for triple bottom line impacts, the environmental dimension dominates the literature. Future scholarly activity in ERM will have to take into account the social practices and relationships to process level and firm level performance measurement.

6) There is a conspicuous absence and thus, the need for accounting and finance disciplines to integrate environmental and social value created and impacts avoided into financial decision analysis supporting full cost, and gross future value of ERM projects and practices.

7) The emerging area of ERM involving food production and food systems [183].

The impact of these factors of the success and effectiveness of ERM programs requires further examination.

\section{Conclusions}

The objective of this literature review was to identify previous efforts and guide future research in the ERM field. The review of the ERM literature reveals the formative years tilted heavily toward conceptual analyses and anecdotal case examples. In the 1990s we started to see empirical studies that undertake hypothesis generation and theory testing [26] [184]. Most applied studies charted a continuum of approaches that companies display toward ERM [25] [44] [154] [157] [185]-[190].

The development of a strong theoretical foundation for ERM got a foothold in the decade of the 1990s [26] [143]. Without theory, empirical research becomes "data-dredging" and it is impossible to make meaningful sense of empirically generated data [191]. Advancing grounded ERM theory will be accomplished by future research efforts focusing on identifying ERM constructs, scale development, and empirically validating the scales. The early decades of ERM literature suffered from a lack of systematic scale development, content validity, and 
empirical validation. This created an early push-back by managers and scholarly debates over impacts on firm performance and overall generalizability of results. Only when these three criteria for theory building (scales, validity, and validation) are accomplished can empirical studies be undertaken which involve hypothesis generation and theory testing [130]. Continued empirical research in this direction will be required if the ERM paradigm is to be transformed into a formally and rationally evaluated discipline.

The ERM landscape has changed over time to include topics such as green supply chain management, corporate social sustainability, environmental sustainability, social sustainability and closed-loop economies, and transparency and integrated reporting efforts. This evolution of terminology includes significant growth in the number of papers on ERM and more recently, sustainability indicates the importance of this paradigm for further, multimethod-based research. Paralleling this growth in publications is the availability of resources to help practitioners and the dissemination of best practices (see Appendix 1 for many of the most used resource).

Trends from the reviewed literature are that social attributes of performance measurement will have both relevance and a growing presence within the ERM field. As this field advances, there will be growing opportunities for practical outputs from future multi-disciplinary research including models and tools that would indicate maturity of the ERM field of inquiry. There is ample opportunity for an integrated approach to research that posits and tests relationships between financial, environmental, and social performance in order to obtain a more integrated understanding of ERM. For those disciplines with low ERM research productivity, we need to ask why. Are editors and researchers uninterested in ERM? Does the paradigm fail to provide an avenue for theoretical contributions? If so, is there an opportunity for scholars to create the necessary linkage for new streams of research? Continued work with practitioners within innovative organizations provides great potential for translating ERM theory into practice. To those scholars who want to understand the dynamic and integrated relationships of ERM, there await numerous opportunities for impactful work previously hidden, but now evident.

\section{References}

[1] Hoffman, J. (2008) Census Peek: Collaboration in the New York City Catskill/Delaware Watershed: Case Study 1990-2000. Environment, Development and Sustainability, 10, 129-156. http://dx.doi.org/10.1007/s10668-006-9042-7

[2] Mayr, E. (1982) The Growth of Biological Thought: Diversity, Evolution, and Inheritance. Harvard University Press, Cambridge.

[3] McKelvey, B. (1982) Organizational Systematics: Taxonomy, Evolution, and Classification. University of California Press, Berkeley.

[4] Chrisman, J.J., Hofer, C.W. and Boulton, W.R. (1988) Toward a System for Classifying Business Strategies. Academy of Management Review, 13, 413-428.

[5] Porter, M.E. (1980) Competitive Strategy. The Free Press, New York.

[6] Abell, D.F. (1980) Defining the Business: The Starting Point of Strategic Planning. Prentice-Hall, Englewood Cliffs.

[7] Hatten, K.J. (1974) Strategic Models in the Brewing Industry. Unpublished Doctoral Dissertation, Purdue University, West Lafayette.

[8] McKelvey, B. (1978) Organizational Systematics: Taxanomic Lessons from Biology. Management Science, 24, 14281440. http://dx.doi.org/10.1287/mnsc.24.13.1428

[9] Roth, K. and Pierce II, J.A. (1986) Strategic Management Taxonomic Research: Critique, Integration, and Casual Model Proposition. Proceeding of the Annual Meeting of the Academy of Management, Chicago, 6-22.

[10] Bock, W.J. (1979) Philosophical Foundations of Classical Evolutionary Classification. Systematic Zoology, 28, 375392.

[11] Sneath, P.H. and Sokal, R.R. (1973) Numerical Taxonomy: The Principles and Practices of Numerical Classification. Freeman, San Francisco.

[12] Carpenter, G.D. (1991) Total Quality Management: A Journey to Environmental Excellence. Environment Today, 27, 45-52.

[13] Frondel, M., Horbach, J. and Rennings, K. (2004) End-of-Pipe or Cleaner Production? An Empirical Comparison of Environmental Innovation Decisions across OECD Countries. An Empirical Comparison of Environmental Innovation Decisions across OECD Countries 04-082.

[14] Berry, M.A. and Rondinelli, D.A. (1998) Proactive Corporate Environmental Management: A New Industrial Revolution. The Academy of Management Executive, 12, 38-50. http://dx.doi.org/10.5465/ame.1998.650515

[15] Buysse, K. and Verbeke, A. (2003) Proactive Environmental Strategies: A Stakeholder Management Perspective. Stra- 
tegic Management Journal, 24, 453-470. http://dx.doi.org/10.1002/smj.299

[16] Ackoff, R.L. (1978) The Art of Problem Solving. John Wiley \& Sons, New York.

[17] (1989) State-of-the-Art Environmental, Health, and Safety Management Programs: How Do You Compare? Arthur D. Little, Inc., Center for Environmental Assurance, Cambridge.

[18] Sarkis, J. and Rasheed, A. (1995) Greening the Manufacturing Function. Business Horizons, 38, 17-27. http://dx.doi.org/10.1016/0007-6813(95)90032-2

[19] Florida, R. (1996) Lean and Green: The Move to Environmentally Conscious Manufacturing. California Management Review, 39, 80-105. http://dx.doi.org/10.2307/41165877

[20] Gupta, M. and Sharma, K. (1996) Environmental Operations Management: An Opportunity for Improvement. Production and Inventory Management Journal, 37, 40-46.

[21] Melnyk, S.A. and Handfield, R.B. (1995) Environmentally Responsible Manufacturing. APICS Conference.

[22] Makower, J. (1993) The E-Factor: The Bottom-Line Approach to Environmentally Responsible Business. Tiden Press, Inc., New York.

[23] Makower, J. (1994) Beyond the Bottom Line: Business for Social Responsibility. Tiden Press, Inc., New York.

[24] Melnyk, S.A., Handfield, R.B., Calantone, R.J. and Curkovic, S. (2001) Integrating Environmental Concerns into the Design Process: The Gap between Theory and Practice. IEEE Transactions on Engineering Management, 48, $189-208$. http://dx.doi.org/10.1109/17.922478

[25] Logsdon, J.M. (1985) Organizational Responses to Environmental Issues: Oil Refining Companies and Air Pollution. In: Preston, L.E., Ed., Research in Corporate Social Performance and Policy, Vol. 7, JAI Press, Inc., Greenwich, 4771.

[26] Klassen, R.D. (1995) The Implications of Environmental Management Strategy for Manufacturing Performance. Doctoral Dissertation, University of North Carolina, Chapel Hill.

[27] Environmental Protection Agency (1992) Total Cost Assessment: Accelerating Industrial Pollution Prevention through Innovative Analysis with Applications to the Pulp and Paper Industry. Report No. EPA/741/R-92/002, Office of Pollution Prevention and Toxics, Washington DC.

[28] Jose, A. and Lee, S.M. (2007) Environmental Reporting of Global Corporations: A Content Analysis Based on Website Disclosures. Journal of Business Ethics, 72, 307-321. http://dx.doi.org/10.1007/s10551-006-9172-8

[29] Montabon, F., Sroufe, R. and Narasimhan, R. (2007) An Examination of Corporate Reporting, Environmental Management Practices and Firm Performance. Journal of Operations Management, 25, 998-1014. http://dx.doi.org/10.1016/j.jom.2006.10.003

[30] Porter, M.E. and van der Linde, C. (1995) Toward a New Conception of Environment-Competitiveness Relationship. Journal of Economic Perspectives, 9, 97-118. http://dx.doi.org/10.1257/jep.9.4.97

[31] Greenstone, M. (2001) The Impacts of Environmental Regulations on Industrial Activity: Evidence from the 1970 \& 1977 Clean Air Act Amendments and the Census of Manufactures. No. w8484, National Bureau of Economic Research.

[32] Xing, Y. and Kolstad, C.D. (2002) Do Lax Environmental Regulations Attract Foreign Investment? Environmental and Resource Economics, 21, 1-22. http://dx.doi.org/10.1023/A:1014537013353

[33] Nehrt, C. (1998) Maintainability of First Mover Advantages When Environmental Regulations Differ between Countries. Academy of Management Review, 23, 77-97.

[34] Ilgin, M.A. and Gupta, S.M. (2010) Environmentally Conscious Manufacturing and Product Recovery (ECMPRO): A Review of the State of the Art. Journal of Environmental Management, 91, 563-591. http://dx.doi.org/10.1016/j.jenvman.2009.09.037

[35] Bracken, M.C. (1985) Information Technology in Emergency Response and Hazardous Waste Management. Information Society, 3, 361-369. http://dx.doi.org/10.1080/01972243.1985.9960012

[36] Johannson, L. (1993) The Power of IT: How Can Information Technology Support TQEM? Environmental Quality Management, 2, 339-347. http://dx.doi.org/10.1002/tqem.3310020316

[37] Klassen, R.D. and Whybark, D.C. (1999) The Impact of Environmental Technologies on Manufacturing Performance. Academy of Management Journal, 42, 599-615. http://dx.doi.org/10.2307/256982

[38] Sarkis, J. (2001) Manufacturing's Role in Corporate Environmental Sustainability-Concerns for the New Millennium. International Journal of Operations \& Production Management, 21, 666-686. http://dx.doi.org/10.1108/01443570110390390

[39] Melville, N.P. (2010) Information Systems Innovation for Environmental Sustainability. MIS Quarterly, 34, 1-21. 
[40] Orlin, J., Swalwell, P. and Fitzgerald, C. (1993) How to Integrate Information Strategy Planning with Environmental Management Information Systems (Part I). Environmental Quality Management, 3, 193-202. http://dx.doi.org/10.1002/tqem.3310030209

[41] FitzGerald, C. (1994) Environmental Management Information Systems: New Tools for Measuring Performance. Environmental Quality Management, 4, 21-33.

[42] Guide Jr., V.D.R. (2000) Production Planning and Control for Remanufacturing: Industry Practice and Research Needs. Journal of Operations Management, 18, 467-483. http://dx.doi.org/10.1016/S0272-6963(00)00034-6

[43] Curkovic, S., Sroufe, R. and Eckert, J. (2006) A Preliminary Framework for Using Total Cost Assessment in Total Quality Environmental Management. The International Journal of Environmental, Cultural, Economic and Social Sustainability, 1, 81-88.

[44] Epstein, M.J. (1996) Measuring Corporate Environmental Performance: Best Practices for Costing and Managing an Effective Environmental Strategy. The IMA Foundation for Applied Research, Inc., Montvale.

[45] Porter, M.E. and van der Linde, C. (1995) Green and Competitive: Ending the Stalemate. Harvard Business Review, 73, 120-134.

[46] Royston, M.G. (1980) Making Pollution Prevention Pay. Harvard Business Review, 58, 6-22.

[47] Rusinko, C.A. (2007) Green Manufacturing: An Evaluation of Environmentally Sustainable Manufacturing Practices and Their Impact on Competitive Outcomes. IEEE Transactions on Engineering Management, 54, 445-454. http://dx.doi.org/10.1109/tem.2007.900806

[48] Zhu, Q. and Sarkis, J. (2004) Relationships between Operational Practices and Performance among Early Adopters of Green Supply Chain Management Practices in Chinese Manufacturing Enterprises. Journal of Operations Management, 22, 265-289. http://dx.doi.org/10.1016/j.jom.2004.01.005

[49] González-Benito, J. and González-Benito, O. (2005) Environmental Proactivity and Business Performance: An Empirical Analysis. Omega, 33, 1-15. http://dx.doi.org/10.1016/j.omega.2004.03.002

[50] Smart, B. (1992) Beyond Compliance. World Resources Institute, Washington DC.

[51] Walley, N. and Whitehead, B. (1994) It’s Not Easy Being Green. Harvard Business Review, 72, 46-52.

[52] Piet, J. (1994) The Challenge of Going Green. Harvard Business Review, 72, 42-43.

[53] Curkovic, S. and Sroufe, R. (2007) The Missing Link to Assessing Total Quality Environmental Management: Total Cost Assessment. The International Journal of Production Economics, 105, 560-579. http://dx.doi.org/10.1016/j.ijpe.2006.04.021

[54] Klassen, R.D. and McLaughlin, C.P. (1996) The Impact of Environmental Management on Firm Performance. Management Science, 42, 1199-1214.

[55] Hart, S.L. (1995) A Natural-Resource-Based View of the Firm. Academy of Management Review, 20, 986-1014.

[56] Russo, M.V. and Fouts, P.A. (1997) A Resource-Based Perspective on Corporate Environmental Performance and Profitability. Academy of Management Journal, 40, 534-559. http://dx.doi.org/10.2307/257052

[57] Konar, S. and Cohen, M.A. (2001) Does the Market Value Environmental Performance? Review of Economics and Statistics, 83, 281-289. http://dx.doi.org/10.1162/00346530151143815

[58] Vachon, S. and Klassen, R.D. (2008) Environmental Management and Manufacturing Performance: The Role of Collaboration in the Supply Chain. International Journal of Production Economics, 111, 299-315. http://dx.doi.org/10.1016/j.ijpe.2006.11.030

[59] Wever, G.H. and Vorhauer, G.F. (1993) Kodak’s Framework and Assessment Tool for Implementing TQEM. Environmental Quality Management, 3, 19-30.

[60] Mizuno, S. (1988) Management for Quality Improvement: The Seven New QC Tools. Productivity Press, Cambridge.

[61] Hunt, C.B. and Auster, E.R. (1990) Proactive Environmental Management: Avoiding the Toxic Trap. Sloan Management Review, 31, 7-18.

[62] Govindarajulu, N. and Daily, B.F. (2004) Motivating Employees for Environmental Improvement. Industrial Management \& Data Systems, 104, 364-372. http://dx.doi.org/10.1108/02635570410530775

[63] Florida, R. and Davison, D. (2001) Gaining from Green Management: Environmental Management Systems inside and outside the Factory. California Management Review, 43, 64-84. http://dx.doi.org/10.2307/41166089

[64] Sroufe, R. (2003) Effects of Environmental Management Systems on Environmental Management Practices and Operations. Production and Operations Management, 12, 416-431.

[65] Kiker, G.A., et al. (2005) Application of Multicriteria Decision Analysis in Environmental Decision Making. Integrated Environmental Assessment and Management, 1, 95-108. http://dx.doi.org/10.1897/IEAM_2004a-015.1 
[66] Kleiner, A. (1991) What Does It Mean to Be Green? Harvard Business Review, 69, 38-47.

[67] Post, J.E. (1991) Managing as if the Earth Mattered. Business Horizons, 34, 32-38. http://dx.doi.org/10.1016/0007-6813(91)90004-F

[68] Wiener, J.L. and Doescher, T.A. (1995) Green Marketing and Selling Brotherhood. Environmental Marketing. Hawthorn Press, Binghamton, 343-358.

[69] Williams, M. (1991) Using Cross-Functional Teams to Integrate Environmental Issues into Corporate Decisions. GEMI Conference Proceedings, Corporate Quality/Environmental Management: The First Conference, Global Environmental Management Initiative, Washington DC, 139-142.

[70] McCormack, M., Jin, S. and Kammlott, G.W. (1995) The Design and Properties of New, Pb-Free Solder Alloys. Proceedings of the IEEE International Symposium on Electronics \& the Environment, Orlando, 1-3 May 1995, 171-176. http://dx.doi.org/10.1109/isee.1995.514970

[71] Sheng, P., Beckman, S., Rosen, C., Worchach, P. and Berkowitz, J. (1996) Hierarchical Metrics for Environmentally Conscious Manufacturing. Proceedings of the National Science Foundation Design and Manufacturing Grantees Conference, Washington DC, 237-238.

[72] Ellram, L.M., Tate, W. and Carter, C.R. (2008) Applying 3DCE to Environmentally Responsible Manufacturing Practices. Journal of Cleaner Production, 16, 1620-1631. http://dx.doi.org/10.1016/j.jclepro.2008.04.017

[73] Montabon, F., Sroufe, R. and Melnyk, S. (2011) Integration of Environmental Management into Manufacturing Planning. Production and Inventory Management Journal, 47, 43-55.

[74] Bowman, S.A. (1996) Design for the Environment: Tools and Techniques. Proceedings of the Decision Sciences Institute, Orlando, November 1996, 24-26.

[75] Fiskel, J. (1993) Quality Metrics in Design for Environment. Environmental Quality Management, 3, 181-192. http://dx.doi.org/10.1002/tqem.3310030208

[76] Fiskel, J. (1996) Design for Environment: Creating Eco-Efficient Products and Processes. McGraw-Hill, New York.

[77] Allenby, B.R. (1993) Industrial Ecology. Prentice-Hall, New York.

[78] Van Weenen, S.C. and Eekels, J. (1989) Design and Waste Prevention. The Environmental Professional, 11, $231-235$.

[79] Melnyk, S.A., Handfield, R.B., Calantone, R.B. and Curkovic, S. (1996) Integrating Environmental Concerns into the Design Process: The Gap between Theory and Practice. Proceedings of the Annual Meeting of the Decision Sciences Institute, Orlando, November 1996, 24-26.

[80] Sroufe, R., Curkovic, S., Montabon, F. and Melnyk, S.A. (2000) The New Product Design Process and Design for Environment: Crossing the Chasm. International Journal of Operations and Production Management, 20, 267-291. http://dx.doi.org/10.1108/01443570010304297

[81] Franke, D.L. and Monroe, K.R. (1995) Innovative Uses of Tools in the Design for the Environment. Proceedings of the IEEE International Symposium on Electronics \& the Environment, Orlando, 1-3 May 1995, 113-117. http://dx.doi.org/10.1109/isee.1995.514961

[82] Shelton, R.D. (1995) Organizing for Successful DFE: Lessons from Winners and Losers. Proceedings of the IEEE International Symposium on Electronics and the Environment, 1-3 May 1995, 1-4. http://dx.doi.org/10.1109/isee.1995.514938

[83] Curkovic, S. and Landeros, R. (2000) An Environmental Baldrige? American Journal of Business, 15, 63-76. http://dx.doi.org/10.1108/19355181200000012

[84] Curkovic, S., Melnyk, S.A., Handfield, R.B. and Calantone, R.J. (2000) Investigating the Linkage between Total Quality Management and Environmentally Responsible Manufacturing. IEEE Transactions on Engineering Management, 47, 444-464. http://dx.doi.org/10.1109/17.895340

[85] Curkovic, S., Sroufe, R. and Melnyk, S.A. (2005) Identifying the Factors Which Affect the Decision to Attain ISO 14000. Journal of Energy, 30, 1387-1407. http://dx.doi.org/10.1016/j.energy.2004.02.016

[86] Global Environmental Management Initiative (GEMI) (1993) Total Quality Environmental Management: The Primer. GEMI, Washington DC.

[87] Blacker, S.M. and Fratoni, S. (1990) Data Quality and the Environment. Quality, 29, 38-42.

[88] May, D.R. and Flannery, B.L. (1995) Cutting Waste with Employee Involvement Teams. Business Horizons, 38, $28-38$. http://dx.doi.org/10.1016/0007-6813(95)90033-0

[89] Graedel, T. and Allenby, B.R. (1995) Industrial Ecology. Prentice Hall, Englewood Cliffs.

[90] Cahan, J. and Schweiger, M. (1993) Product Life Cycle: The Key to Integrating EHS into Corporate Decision Making and Operations. Environmental Quality Management, 3, 141-150. http://dx.doi.org/10.1002/tqem.3310030203 
[91] Brent, A.C. and Visser, J.K. (2005) An Environmental Performance Resource Impact Indicator for Life Cycle Management in the Manufacturing Industry. Journal of Cleaner Production, 13, 557-565. http://dx.doi.org/10.1016/j.jclepro.2003.12.007

[92] Gloria, T., Saad, T., Breville, M. and O’Connel, M. (1995) Life-Cycle Assessment: A Survey of Current Implementation. Environmental Quality Management, 4, 33-50. http://dx.doi.org/10.1002/tqem.3310040306

[93] Morgan, M. and Munilla, L.S. (1995) The Eco-Marketing Orientation: An Emerging Business Philosophy. Environmental Marketing. Hawthorn Press, Binghamton, 23-33.

[94] Hastings, H.M. (1991) A Dance with the Devil. Chief Executive, 71, 44-46.

[95] Coddington, W. (1993) Environmental Marketing’s New Relationship with Corporate Environmental Management. Environmental Quality Management, 2, 297-302. http://dx.doi.org/10.1002/tqem.3310020310

[96] Davis, J.J. (1992) Ethics and Environmental Marketing. Journal of Business Ethics, 11, 81-87. http://dx.doi.org/10.1007/BF00872314

[97] Droge, C., Calantone, R., Agrawal, M. and Mackoy, R. (1993) The Consumption Culture and Its Critiques: Framework for Analysis. Journal of Macromarketing, 13, 32-45. http://dx.doi.org/10.1177/027614679301300205

[98] Stundza, T. (1992) You and the Environment. Purchasing, 112, 49-53.

[99] Johannson, L. (1994) How Can a TQEM Approach Add Value to Your Supply Chain? Environmental Quality Management, 3, 521-530. http://dx.doi.org/10.1002/tqem.3310030413

[100] Curkovic, S. and Sroufe, R. (2011) Using ISO 14000 to Promote a Sustainable Supply Chain Strategy. The International Journal of Business Strategy and the Environment, 20, 71-93. http://dx.doi.org/10.1002/bse.671

[101] Avery, S. (1994) Purchasing Is at the Root of Scott’s Green Efforts. Purchasing, 117, 48-49.

[102] Finn, S. (1994) President of Supply Chain Management, a Toronto-Based Consulting Firm Specializing in Supply Chain Management. Appeared in: Johannson, L., How Can a TQEM Approach Add Value to Your Supply Chain? Environmental Quality Management, 521-530.

[103] Bragdon, J. and Marlin, J. (1972) Is Pollution Profitable? Risk Management, 19, 9-18.

[104] Sarkis, J. and Cordeiro, J.J. (2001) An Empirical Evaluation of Environmental Efficiencies and Firm Performance: Pollution Prevention versus End-of-Pipe Practice. European Journal of Operational Research, 135, 102-113. http://dx.doi.org/10.1016/S0377-2217(00)00306-4

[105] Global Environmental Management Initiative (GEMI) (1996) ISO 14000 Environmental Management System SelfAssessment Checklist. GEMI, Washington DC.

[106] Bunse, K. (2011) Integrating Energy Efficiency Performance in Production Management—Gap Analysis between Industrial Needs and Scientific Literature. Journal of Cleaner Production, 19, 667-679. http://dx.doi.org/10.1016/j.jclepro.2010.11.011

[107] Bronstein, S. (1989) Southern Poll: Environment a Problem, but Not a Top One. Atlanta Journal, A1.

[108] Rosewicz, B. (1990) Americans Are Willing to Sacrifice to Reduce Pollution, They Say. Wall Street Journal, A1.

[109] Epstein, M.J. (1991) What Shareholders Really Want. New York Times, 11.

[110] Gutfield, R. (1991) Eight of Ten Americans Are Environmentalists, at Least so They Say. Wall Street Journal, A1.

[111] Welford, R. and Gouldson, A. (1993) Environmental Management and Business Strategy. Pittman, London.

[112] Altany, D. (1989) Views from the Corner Office. Industry Week, 238, 11-18.

[113] Altany, D. (1990) The Vision Thing. Industry Week, 239, 20-28.

[114] Ferguson, A. (1989) Good to Be Green. Management Today, 46-52.

[115] Zetlin, M. (1990) The Greening of Corporate America. Management Review, 79, 10-17.

[116] Gore, A. (1993) Earth in the Balance: Ecology and the Human Spirit. Houghton Mifflin, Boston.

[117] Cairncross, F. (1991) Costing the Earth: The Challenge for Governments, the Opportunities for Business. Harvard Business School Press, Boston.

[118] Schmidheiny, S. and the Business Council for Sustainable Development (1992) Changing Course: A Global Business Perspective on Development and the Environment. MIT Press, Cambridge.

[119] Stead, W.E. and Stead, J.G. (1992) Management for a Small Planet. Sage, Newbury Park.

[120] Elkington, J. (2012) The Zeronauts: Breaking the Sustainability Barrier. Routledge, Abingdon.

[121] McDonough, W., Braungart, M., Anastas, P.T. and Zimmerman, J.B. (2003) Applying the Principle of Green Engineering to Cradle-to-Cradle Design. Environmental Science \& Technology, 37, A434-A441. 
[122] Savitz, A.W. and Weber, K. (2007) The Sustainability Sweet Spot. Environmental Quality Management, 17, 17-28. http://dx.doi.org/10.1002/tqem.20161

[123] Hunter, R.D. (1993) Standardization and the Environment. International Environment Reporter, 185-191. (1994) ISO 14000: Global Environmental Standard Has Trade Implications. Environmental Manager's Compliance Advisor, 376, 3-5.

[124] Jaffe, A.B., Peterson, S.R., Portney, P.R. and Stavins, R.N. (1994) Environmental Regulation and the Competitiveness of U.S. Manufacturing: What Does the Evidence Tell Us? Journal of Economic Literature, 33, 132-163.

[125] Karls, B. (1993) Overseas E-Management: An Opportunity to Beat the Crunch. Environment Today, 4, 36-38.

[126] Balikov, H.R. (1995) Developing Global Environmental Management Standards-Progress and Implications of the New Wave. Environmental Quality Management, 4, 1-4. http://dx.doi.org/10.1002/tqem.3310040302

[127] Walter, M. (1994) Multinationals Broaden Environmental Horizons. Hazmat World, 7, 46-52.

[128] Zsidisin, G.A. and Siferd, S.P. (2001) Environmental Purchasing: A Framework for Theory Development. European Journal of Purchasing \& Supply Management, 7, 61-73. http://dx.doi.org/10.1016/S0969-7012(00)00007-1

[129] Wagner, M. and Schaltegger, S. (2004) The Effect of Corporate Environmental Strategy Choice and Environmental Performance on Competitiveness and Economic Performance: An Empirical Study of EU Manufacturing. European Management Journal, 22, 557-572.

[130] Curkovic, S. (2003) Environmentally Responsible Manufacturing: The Development and Validation of a Measurement Model. European Journal of Operational Research, 146, 130-155. http://dx.doi.org/10.1016/S0377-2217(02)00182-0

[131] Melnyk, S.A., Sroufe, R.P. and Calantone, R. (2003) Assessing the Impact of Environmental Management Systems on Corporate and Environmental Performance. Journal of Operations Management, 21, 329-351. http://dx.doi.org/10.1016/S0272-6963(02)00109-2

[132] Darnall, N., Henriques, I. and Sadorsky, P. (2008) Do Environmental Management Systems Improve Business Performance in an International Setting? Journal of International Management, 14, 364-376. http://dx.doi.org/10.1016/j.intman.2007.09.006

[133] Darnall, N., Jolley, G.J. and Handfield, R. (2008) Environmental Management Systems and Green Supply Chain Management: Complements for Sustainability? Business Strategy and the Environment, 17, 30-45. http://dx.doi.org/10.1002/bse.557

[134] Alm, A.L. (1992) ES\&T Regulatory Focus: Pollution Prevention and TQM: Examples of Paradigm Shifts. Environmental Science \& Technology, 26, 452. http://dx.doi.org/10.1021/es00027a601

[135] Friedman, F.B. (1992) The Changing Role of the Environmental Manager. Business Horizons, 35, 25-28.

[136] Wheeler, W.A. (1992) The Revival in Reverse Manufacturing. Journal of Business Strategy, 13, 8-13. http://dx.doi.org/10.1108/eb039499

[137] Willig, J. (1994) Environmental TQM. McGraw-Hill, Inc., New York.

[138] Shrivastava, P. (1995) The Role of Corporations in Achieving Ecological Sustainability. Academy of Management Review, 20, 936-960.

[139] De Oliveira Matias, J.C. and Coelho, D.A. (2002) The Integration of the Standards Systems of Quality Management, Environmental Management and Occupational Health and Safety Management. International Journal of Production Research, 40, 3857-3866. http://dx.doi.org/10.1080/00207540210155828

[140] Habicht, H. (1991) TQM at the Environmental Protection Agency. GEMI Conference Proceedings, Corporate Quality/Environmental Management: The First Conference, Global Environmental Management Initiative, Washington DC, $17-21$.

[141] Flannery, B. and May, D. (1994) Prominent Factors Influencing Environmental Activities: Application of the Environmental Leadership Model (ELM). Leadership Quarterly, 5, 201-221. http://dx.doi.org/10.1016/1048-9843(94)90012-4

[142] King, A.A. and Lenox, M.J. (2001) Lean and Green? An Empirical Examination of the Relationship between Lean Production and Environmental Performance. Production and Operations Management, 10, 244-256. http://dx.doi.org/10.1111/j.1937-5956.2001.tb00373.x

[143] Post, J.E. and Altman, B.W. (1992) Models of Corporate Greening: How Corporate Social Policy and Organizational Learning Inform Leading-Edge Environmental Management. Research in Corporate Social Performance and Policy, 13, 3-29.

[144] Pun, K.F. (2006) Determinants of Environmentally Responsible Operations: A Review. International Journal of Quality \& Reliability Management, 23, 279-297. http://dx.doi.org/10.1108/02656710610648233

[145] McGee, E.C. and Bhushman, A.K. (1993) Applying the Baldrige Quality Criteria to Environmental Performance: Les- 
sons Learned from Leading Organizations. Environmental Quality Management, 3, 1-18. http://dx.doi.org/10.1002/tqem.3310030102

[146] O’Dea, K. and Pratt, K. (1995) Achieving Environmental Excellence through TQEM Strategic Alliances. Environmental Quality Management, 4, 93-108.

[147] Molina-Azorín, J.F., et al. (2009) Quality Management, Environmental Management and Firm Performance: A Review of Empirical Studies and Issues of Integration. International Journal of Management Reviews, 11, 197-222. http://dx.doi.org/10.1111/j.1468-2370.2008.00238.x

[148] Global Environmental Management Initiative (GEMI) (1994) Environmental Self-Assessment Program. 3rd Edition, GEMI, Washington DC.

[149] Enander, R.T. and Pannullo, D. (1990) Employee Involvement and Pollution Prevention. Journal of Quality \& Participation, 1, 50-53.

[150] Cook, J. and Seith, B.J. (1991) Environmental Training: A Tool for Assuring Compliance. Journal of Environmental Regulation, 1, 167-172.

[151] Cook, J. and Seith, B.J. (1992) Designing an Effective Environmental Training Program. Journal of Environmental Regulation, 2, 53-62.

[152] Cramer, J.M. and Roes, B. (1993) Total Employee Involvement: Measures for Success. Environmental Quality Management, 3, 39-52. http://dx.doi.org/10.1002/tqem.3310030105

[153] Gripman, S.R. (1991) How to Involve Employees in Solid Waste Reduction. Environmental Manager, 3, 9-10.

[154] Marguglio, B.W. (1990) Environmental Management Systems. M. Dekker, New York.

[155] Daily, B.F. and Huang, S. (2001) Achieving Sustainability through Attention to Human Resource Factors in Environmental Management. International Journal of Operations \& Production Management, 21, 1539-1552. http://dx.doi.org/10.1108/01443570110410892

[156] Ahire, S.L., Landeros, R. and Golhar, D.Y. (1995) Total Quality Management: A Literature Review and an Agenda for Future Research. Production and Operations Management, 4, 277-306. http://dx.doi.org/10.1111/j.1937-5956.1995.tb00057.x

[157] Schot, J. (1991) The Greening of the Chemical Industry: An Assessment. TNO Center for Technology and Policy Studies, The Netherlands.

[158] Bemowski, K. (1991) Sorting Fact from Fiction. Quality Progress, 24, 21-25.

[159] Angell, L.C. and Klassen, R.D. (1999) Integrating Environmental Issues into the Mainstream: An Agenda for Research in Operations Management. Journal of Operations Management, 17, 575-598. http://dx.doi.org/10.1016/S0272-6963(99)00006-6

[160] Theyel, G. (2000) Management Practices for Environmental Innovation and Performance. International Journal of Operations \& Production Management, 20, 249-266. http://dx.doi.org/10.1108/01443570010304288

[161] Christmann, P. (2000) Effects of Best Practices of Environmental Management on Cost Advantage: The Role of Complementary Assets. Academy of Management Journal, 43, 663-680. http://dx.doi.org/10.2307/1556360

[162] Sarkis, J. (1998) Evaluating Environmentally Conscious Business Practices. European Journal of Operational Research, 107, 159-174. http://dx.doi.org/10.1016/S0377-2217(97)00160-4

[163] Danesi, P.P. (1996) Project Chair for the Project Committee of the IMA Foundation for Applied Research, Inc., Texas Instruments, Attleboro, Massachusetts. Appeared in: Epstein, M.J., Measuring Corporate Environmental Performance: Best Practices for Costing and Managing an Effective Environmental Strategy. The IMA Foundation for Applied Research, Inc., Montvale.

[164] Esty, D. and Winston, A. (2006) It’s Easy Being Green. Forbes, 178, 34.

[165] Porter, M.E. (1991) America’s Green Strategy. Scientific American, 264, 168. http://dx.doi.org/10.1038/scientificamerican0491-168

[166] Aupperle, K.E., Caroll, A.B. and Hatfield, J.D. (1985) An Empirical Examination of the Relationship between Corporate Social Responsibility and Profitability. Academy of Management Journal, 28, 446-463. http://dx.doi.org/10.2307/256210

[167] Capon, N., Farley, J.U. and Hoenig, S. (1990) Determinants of Financial Performance: A Meta-Analysis. Management Science, 36, 1143-1159. http://dx.doi.org/10.1287/mnsc.36.10.1143

[168] Ullmann, J. (1985) Data in Search of a Theory: A Critical Examination of the Relationships among Social Performance, Social Disclosure and Economic Performance of U.S. Firms. Academy of Management Review, 10, 540-557. http://dx.doi.org/10.5465/amr.1985.4278989

[169] Jaffe, A.B., Peterson, S.R., Portney, P.R. and Stavins, R.N. (1993) Environmental Regulations and the Competitiveness 
of U.S. Industry. Economics Resource Group, Cambridge, MA.

[170] Oates, W.E., Palmer, K.L. and Pourtney, P.R. (1993) Environmental Regulation and International Competitiveness: Thinking about the Porter Hypothesis. Resources for the Future, Working Paper 94-02.

[171] Palmer, K.L. and Simpson, R.D. (1993) Environmental Policy as Industrial Policy. Resources, vol., 17-21.

[172] Simpson, R.D. (1993) Taxing Variable Cost: Environmental Regulation as Industrial Policy. Resources for the Future, Working Paper ENR93-12.

[173] Schmalensee, R. (1993) The Costs of Environmental Regulations. Massachusetts Institute of Technology, Center for Energy and Environmental Policy Research, Working Paper 93-015.

[174] Palmer, K., Oates, W.E. and Portney, P.R. (1995) Tightening Environmental Standards: The Benefit-Cost or No-Cost Paradigm? Journal of Economic Perspectives, 9, 119-132. http://dx.doi.org/10.1257/jep.9.4.119

[175] Bonifant, B. and Ratcliffe, I. (1994) Competitive Implications of Environmental Regulation in the Pulp and Paper Industry. Management Institute for Environment and Business, Washington DC.

[176] Bonifant, B. (1994) Competitive Implications of Environmental Regulation in the Electronics Manufacturing Industry. Management Institute for Environment and Business, Washington DC.

[177] Bonifant, B. (1994) Competitive Implications of Environmental Regulation in the Paint and Coatings Industry. Management Institute for Environment and Business, Washington DC.

[178] Van der Linde, C. (1995) Competitive Implications of Environmental Regulation in the Cell Battery Industry. Hochschule St. Gallen, St. Gallen, forthcoming.

[179] Van der Linde, C. (1995) Competitive Implications of Environmental Regulation in the Printing Ink Industry. Hochschule St. Gallen, St. Gallen, forthcoming.

[180] Fischer, K. and Schot, J., Eds. (1993) Environmental Strategies for Industry: International Perspectives on Research Needs and Policy Implications. Inland Press, Washington DC.

[181] Lee, S.Y. and Klassen, R.D. (2008) Drivers and Enablers That Foster Environmental Management Capabilities in Small- and Medium-Sized Suppliers in Supply Chains. Production and Operations Management, 17, 573-586. http://dx.doi.org/10.3401/poms.1080.0063

[182] Lawrence, J. and Colford, S.W. (1991) Green Guidelines are the Next Step. Advertising Age, 62, 28.

[183] Lockie, S., Lyons, K. and Lawrence, G. (2006) Going Organic: Mobilizing Networks for Environmentally Responsible Food Production. CABI. http://dx.doi.org/10.1079/9781845931322.0000

[184] Vastag, G., Kerekes, S. and Rondinelli, D.A. (1996) Evaluation of Corporate Environmental Management Approaches: A Framework and Application. International Journal of Production Economics, 43, 193-211. http://dx.doi.org/10.1016/0925-5273(96)00040-0

[185] Mahon, J.F. (1983) Corporate Political Strategies: An Empirical Study of Chemical Firm Responses to Superfund Legislation. In: Preston, L.E., Ed., Research in Corporate Social Performance and Policy, Vol. 5, JAI Press, Inc., Greenwich, 143-182.

[186] Miles, R.T. (1987) Managing the Corporate Social Environment: A Grounded Theory. Prentice-Hall, Englewood Cliffs.

[187] Petulla, J.M. (1987) Environmental Management in Industry. Journal of Professional Issues in Engineering, 113, 167183. http://dx.doi.org/10.1061/(ASCE)1052-3928(1987)113:2(167)

[188] Clarkson, M.B.E. (1991) Defining, Evaluating, and Managing Corporate Social Performance: The Stakeholder Management Model. In: Post, J.E., Ed., Research in Corporate Social Performance and Policy, Vol. 12, JAI Press Inc., Greenwich, 331-358.

[189] Greening, D.W. (1992) Organizing for Public Issues: Environmental and Organizational Predictors of Structure and Process. In: Post, J.E., Ed., Research in Corporate Social Performance and Policy, Vol. 13, JA1 Press, Inc., Greenwich, 83-117.

[190] Arnfalk, P. and Thidell, A. (1992) Environmental Management in the Swedish Manufacturing Industry. Unpublished paper, Department of Industrial Engineering, Lund University, Lund.

[191] Kerlinger, F.N. (1986) Foundations of Behavioral Research. 3rd Edition, Harcourt Brace Jovanovich College Publishers, Fort Worth. 


\section{Appendix 1. ERM Relevant On-Line Resources}

Developed mostly over the last two decades, there are now a number of ERM web-based resources available: Principles Standards and Goals

- GEMI http://gemi.org/

- EMAS http://ec.europa.eu/environment/emas/index_en.htm

- UNPRME http://www.unprme.org/

- UN Sustainable Development Goals http://www.un.org/sustainabledevelopment/sustainable-development-goals/

Corporate Responsibility Consultancy

- SustainAbility http://www.sustainability.com/

- The Natural Step http://www.thenaturalstep.org/

- BCG http://www.bcg.com/expertise/capabilities/sustainability/default.aspx

- $\quad \mathrm{PwC}$ http://www.pwc.com/gx/en/services/sustainability.html

- $\mathrm{KPMG}$ https://home.kpmg.com/xx/en/home/services/advisory/risk-consulting/internal-audit-risk/sustainability-services.html

Standardized Reporting

- GRI https://www.globalreporting.org/Pages/default.aspx

- CDP https://www.cdp.net/en-US/Pages/HomePage.aspx

- SASBY http://www.sasb.org/

- IIRC http://integratedreporting.org/

- GHG Protocol http://www.ghgprotocol.org/

Buildings

- USGBC LEED http://www.usgbc.org/LEED/

- Energy Star https://www.energystar.gov/buildings

- Green Globes http://www.greenglobes.com/home.asp

Certification Bodies

- ISO http://www.iso.org/iso/home.html

- Marine Stewardship Council https://www.msc.org/

- Forest Stewardship Council https://us.fsc.org/en-us

ESG Measurement, Indices and Rankings

- MSCI Global Socrates https://www.msci.com/esg-integration

- Dow Jones Sustainability Index http://www.sustainability-indices.com/index-family-overview/djsi-family-overview/index.jsp

- The Corporate Knights http://www.corporateknights.com/us/about-us/

- TruCost http://www.trucost.com/ Networks

- Greenbiz http://www.greenbiz.com

- The Sustainability Consortium https://www.sustainabilityconsortium.org/

UNGC https://www.unglobalcompact.org/ 